\title{
Ciężkie zapalenie płuc o etiologii Pneumocystis jirovecii u pacjentki po przeszczepieniu nerki uczulonej na Biseptol
}

\author{
Severe Pneumocysits jirovecii pneumonia in a patient allergic to Biseptol after kidney \\ transplantation
}

\author{
Joanna Kabat-Koperska ${ }^{\bowtie}$, Małgorzata Marchelek, Grażyna Dutkiewicz, \\ Grzegorz Marcinkowski, Kazimierz Ciechanowski
}

Pomorski Uniwersytet Medyczny w Szczecinie, Klinika Nefrologii, Transplantologii i Chorób Wewnętrznych, al. Powstańców Wlkp. 72, 70-111 Szczecin Pomeranian Medical University in Szczecin, Department of Nephrology, Transplantology and Internal Medicine

$\triangle$ askodom@poczta.onet.pl

\begin{abstract}
Introduction: Pneumocystis jirovecii may cause pneumonia in patients treated with immunosuppression. The clinical course is varied, from mild to severe, similar to acute respiratory distress syndrome with treatment in an intensive care unit.

A case report: In the article we present the case of a 59-year-old female after the third cadaveric kidney transplantation with
\end{abstract}

\section{ABSTRAKT}

Wstęp: Pneumocystis jirovecii wywołuje u pacjentów leczonych immunosupresyjnie zapalenia płuc, których przebieg kliniczny jest zróżnicowany - od przypadków łagodnie przebiegających po ciężkie postacie chorobowe przypominające zespół ostrej niewydolności oddechowej i wymagające leczenia na oddziale intensywnej terapii.

Opis przypadku: W artykule przedstawiono przypadek 59-letniej pacjentki po trzecim z kolei przeszczepieniu nerki od dawcy severe, complicated pneumonia caused by this organism, who was additionally allergic to Co-trimoxazole (Biseptol). We present brief recommendations for prophylaxis and alternative drugs to Biseptol, which can be used in prophylactic treatment in such individuals.

Keywords: kidney transplantation; pneumonia; Pneumocystis; immunosuppression.

zmarłego, ze szczególnie ciężkim, powikłanym przebiegiem zapalenia płuc wywołanego przez ten patogen. Chora była dodatkowo uczulona na kotrimoksazol (Biseptol). Krótko omówiono zasady profilaktyki i leki, które można zastosować w leczeniu profilaktycznym u takich pacjentów zamiast Biseptolu.

Słowa kluczowe: przeszczepienie nerki; pneumonia; Pneumocystis; immunosupresja.

\section{WSTĘP}

Pneumocystis jirovecii to patogen zaliczany do rodziny grzybów, który kolonizuje drogi oddechowe i atakuje głównie pacjentów z osłabioną odpornością. Zakażenie jest rozpowszechnione, kolonizacja dotyczy $20-50 \%$ dorosłych, a przeciwciała przeciwko Pneumocystis ma $80 \%$ dzieci w wieku 4 lat $[1,2]$. Patogen ten nie jest groźny u osób immunologicznie kompetentnych, natomiast osoby po przeszczepieniach narządów otrzymujące leki immunosupresyjne oraz chorzy z AIDS lub z uogólnioną chorobą nowotworową stają się podatni na objawowe zakażenie. Do zakażenia dochodzi drogą kropelkową. Przebieg kliniczny zapalenia płuc wywołanego przez Pneumocystis jirovecii jest zróżnicowany - od przypadków łagodnie przebiegających po ciężkie postacie chorobowe przypominające zespół ostrej niewydolności oddechowej i wymagające leczenia na oddziale intensywnej terapii (OIT). Typowe początkowe objawy to suchy kaszel, gorączka i nasilająca się duszność. Szczyt zachorowań po przeszczepieniu narządu przypada na okres 1-6 miesięcy po zabiegu [3], stąd wiele ośrodków transplantacyjnych na świecie stosuje w tym okresie profilaktykę przeciwko Pneumocystis jirovecii, najczęściej z użyciem kotrimoksazolu.

\section{OPIS PRZYPADKU}

59-letnia pacjentka z przewlekłą niewydolnością nerek na tle prawdopodobnie przewlekłego kłębuszkowego zapalenia nerek została poddana trzeciemu już z kolei przeszczepieniu nerki od dawcy zmarłego 5 maja 2010 r. Czas zimnego niedokrwienia wynosił 12 godz., panel przeciwciał - 56\%, zgodność - 4 pkt. Pierwsza nerka przeszczepiona została w 2001 r., graft funkcjonował 5 lat. W czerwcu 2007 r. wykonano kolejne przeszczepienie nerki od dawcy zmarłego, po roku obserwowano utratę funkcji graftu z powodu nefropatii związanej z zakażeniem wirusem BK; drugi graft wyszczepiono. Przebieg pooperacyjny po trzecim przeszczepieniu był niepowikłany, 
obserwowano natychmiastowe podjęcie funkcji przez nerkę przeszczepioną. W leczeniu immunosupresyjnym zastosowano indukcję bazyliksymabem, takrolimus, mykofenolan mofetylu oraz prednizon. Chora została wypisana do domu po 3 tyg. z kreatyniną 0,82 mg/dL. Obserwowano łagodną postać cukrzycy potransplantacyjnej, która wymagała jedynie zastosowania diety cukrzycowej. W biopsji protokolarnej wykonanej 4 miesiące po przeszczepieniu stwierdzono cechy zakażenia wirusem BK, potwierdzonego za pomocą reakcji łańcuchowej polimerazy DNA (BKV w surowicy - 5718 kopii/mL). Zmniejszono dawkę takrolimusu, dokonano konwersji leczenia z mykofenolanu mofetylu na ewerolimus. Uzyskano eradykację wirusa BK. We wrześniu 2012 r. pojawił się subnerczycowy białkomocz. Wykonano biopsję nerki przeszczepionej, która ujawniła zmiany graniczne (podano 3 pulsy metyloprednizolonu i podwyższono dawkę prednizonu do 1 × $20 \mathrm{mg}$, uzyskano zmniejszenie białkomoczu o połowę). Nie wykazano obecności przeciwciał przeciwko antygenom dawców. W kontrolnie wykonanej biopsji graftu po 3 miesiącach stwierdzono brak cech odrzucania, przewlekłą glomerulopatię graftu, średniego stopnia włóknienie śródmiąższowe/zanik cewek. Poziom kreatyniny wynosił 1,4 mg/dL.

W marcu 2013 r. pojawiły się objawy zakażenia górnych dróg oddechowych (chora otrzymała doustnie amoksycylinę), tydzień później pacjentkę przyjęto do Kliniki Nefrologii, Transplantologii i Chorób Wewnętrznych Pomorskiego Uniwersytetu Medycznego w Szczecinie z kaszlem i gorączką. Wdrożono leczenie empiryczne atypowego zapalenia płuc (klarytromycyna, nystatyna, gancyklowir). Z powodu pogorszenia stanu ogólnego, nasilonej duszności i wysiłku oddechowego oraz objawów niewydolności oddechowej pacjentka została przekazana na OIT. Za pomocą tomografii komputerowej klatki piersiowej stwierdzono w obu płucach konsolidacje zapalne i zmiany o typie „mlecznej szyby”. W płukaniu oskrzelowo-płucnym stwierdzono materiał genetyczny Pneumocystis jirovecii, wykluczając zakażenie innymi patogenami, jak: wirus Epsteina-Barra, wirus RSV, Mycoplasma, Chlamydia, wirus ospy wietrznej. Z powodu uczulenia na kotrimoksazol (w wywiadzie 2-krotnie występował obrzęk Quinckego po podaniu tego leku) w leczeniu zastosowano klindamycynę i prymachinę, a następnie dapson. Z powodu wystąpienia anurii pacjentka była leczona ciągłymi technikami nerkozastępczymi. Pobyt na OIT powikłany był krwawieniem z uchyłków esicy, wymagającym hemikolektomii lewostronnej, uogólnionym zakażeniem grzybiczym (leczonej flukonazolem) z zajęciem gałki oka prawego (wykonano fakowitrektomię) oraz odrespiratorowym zapaleniem płuc wywołanym przez Serratia marcescens ESBL+ (szczepy produkujące beta-laktamazy o rozszerzonym spektrum działania), leczonym za pomocą antybiotykoterapii celowanej. Hospitalizacja na OIT trwała 3 miesiące i 2 tyg. Obserwowano stopniowy powrót diurezy i poprawę wydolności układu oddechowego. Pacjentka po wypisaniu z OIT z kreatyniną rzędu 0,9 mg/dL, wymagająca intensywnej rehabilitacji ruchowej z powodu zaniku i osłabienia siły mięśni. Po upływie 4 dni od wypisu z OIT kobieta została ponownie przyjęta do Kliniki Nefrologii z powodu gorączki, biegunki oraz dolegliwości dyzurycznych. Stwierdzono zakażenie Clostridium difficile oraz cechy zakażenia w układzie moczowym (E. faecalis, a w kolejnym posiewie C. albicans). Wdrożono antybiotykoterapię celowaną oraz dożylne leczenie flukonazolem. Dolegliwości ustąpiły przy prawidłowej funkcji nerki przeszczepionej. Leczenie immunosupresyjne zredukowano do prednizonu w dawce dobowej $20 \mathrm{mg}$. Wdrożono stałą profilaktykę dapsonem w dawce $100 \mathrm{mg} 2$ razy w tyg. i chorą w stanie ogólnym dobrym wypisano do domu.

\section{DYSKUSJA}

Prowadzona w wielu ośrodkach transplantacyjnych na świecie profilaktyka przeciwko Pneumocystis jirovecii zredukowała znacząco liczbę przypadków wczesnych zachorowań po przeszczepieniu narządów. Jednakże pojawia się problem zakażeń tzw. późnych, tj. po zaprzestaniu profilaktyki [4]. Pacjentka, której przypadek został omówiony, nie otrzymywała profilaktyki bezpośrednio po transplantacji z uwagi na wcześniejsze uczulenie na kotrimoksazol objawiające się obrzękiem Quinckego. Szczęśliwie w pierwszym półroczu po przeszczepieniu nerki nie doszło do wystąpienia zakażenia Pneumocystis jirovecii. Jednak wielokrotne transplantacje nerki wiązały się z koniecznością stosowania indukcji oraz z wieloletnią kumulacją narażenia na objawy uboczne leków immunosupresyjnych. Ponadto kobieta 6 miesięcy przed wystąpieniem zakażenia była leczona metyloprednizolonem z powodu stwierdzanych w biopsji nerki przeszczepionej zmian granicznych, po czym podwyższono doustną dawkę prednizonu.

Leczenie epizodów ostrego odrzucania jest uznawane za jeden z czynników ryzyka wystąpienia zapalenia płuc wywołanego przez Pneumocystis jirovecii [5]. Do pozostałych czynników ryzyka zalicza się zakażenie wirusem cytomegalii (u chorej w PCR DNA CMV było ujemne), gruźlicę oraz wirusowe zapalenie wątroby typu C. Kolejnym problemem są metody diagnostyczne - w badaniach obrazowych takich jak zdjęcie rentgenowskie czy tomografia komputerowa klatki piersiowej widać często obraz „mlecznej szyby”, pozwalający jedynie na zakwalifikowanie tego typu zapaleń do śródmiąższowych z kilkoma potencjalnymi infekcyjnymi czynnikami sprawczymi. Pewne rozpoznanie można postawić po stwierdzeniu patogenu w płynie z płukania oskrzelowo-płucnego zabarwionych toluidyną albo po zbadaniu płynu metodą PCR. Ta ostatnia metoda jest łatwa i szybka do wykonania w warunkach OIT u zaintubowanego pacjenta. Na pozostałych oddziałach konieczne jest umówienie bronchoskopii, najlepiej z krótkotrwałym znieczuleniem pacjenta, szczególnie w przypadkach nasilającej się duszności. Może to powodować opóźnienie postawienia właściwego rozpoznania. Jednakże w przypadku wystąpienia zakażeń Pneumocystis jirovecii w danym ośrodku transplantacyjnym należy w kolejnych podejrzanych przypadkach szybko podejmować taką decyzję i wdrożyć ukierunkowane leczenie [4].

Przebycie zakażenia nie pozostawia trwałej odporności, a zastosowanie profilaktyki jest niedrogie i pozbawione ryzyka 
powstania szczepów Pneumocystis opornych na stosowane leki [4]. W ośrodkach, w których odnotowano zapalenia płuc wywołane przez Pneumocystis jirovecii, należy wdrożyć niezwłocznie profilaktykę uniwersalną (jeśli taka nie była stosowana) oraz izolować chorych zakażonych od innych pacjentów leczonych immunosupresyjnie. U chorych uczulonych na kotrimoksazol zarówno w leczeniu, jak i profilaktyce można stosować takie leki jak dapson, dapson/pirymetaminę, pentamidynę wziewną, atowakwon. Opisywana pacjentka była leczona dapsonem. Przebycie zakażenia Pneumocystis jirovecii powoduje konieczność stosowania profilaktyki bezterminowo [4], w prezentowanym przypadku tak długo, jak chora będzie pozostawać na leczeniu immunosupresyjnym. Pozostali pacjenci po przeszczepieniu nerki powinni otrzymywać profilaktykę przez 6-12 miesięcy. W przypadku przeszczepień innych narządów proponuje się 3 miesiące po przeszczepieniu wątroby, 12 miesięcy po przeszczepieniu serca oraz profilaktykę bezterminową po przeszczepieniu płuca [4]. Dłuższą profilaktykę należy rozważyć u pacjentów zakażonych wirusem cytomegalii, leczonych z powodu ostrego odrzucania graftu i u pacjentów z przewlekłą obturacyjną chorobą płuc [6].

\section{PIŚMIENNICTWO}

1. Morris A, Wei K, Afshar K, Huang L. Epidemiology and clinical significance of pneumocystis colonization. J Infect Dis 2008;197(1):10S-7S. doi: 10.1086/523814.

2. Gilroy SA, Bennett NJ. Pneumocystis pneumonia. Semin Respir Crit Care Med 2011;32(6):775S-82S. doi: 10.1055/s-0031-1295725.

3. Danovitch GM. Handbook of kidney transplantation. Philadelphia: Lippincott Willams \& Wilkins; 2001. p. 255.

4. Chapman JR, Marriott DJ, Chen SC, MacDonald PS. Post-transplant Pneumocystis jirovecii pneumonia - a re-emerged public health problem? Kidney Int 2013;84(2):240S-3S.

5. Radisic M, Lattes R, Chapman JF, del Carmen Rial M, Guardia O, Seu F, et al. Risk factors for Pneumocystis carinii pneumonia in kidney transplant recipients: a case-control study. Transpl Infect Dis 2003;5(2):84S-93S.

6. Phipps LM, Chen SC, Kable K, Halliday CL, Firacative C, Meyer W, et al. Nosocomial Pneumocystis jirovecii pneumonia: lessons from a cluster in kidney transplant recipients. Transplantation 2011;92(12):1327S-34S. doi: 10.1097/TP.0b013e3182384b57. 